\title{
Recent Advances in Next Generation Snakebite Antivenoms
}

\author{
Cecilie Knudsen and Andreas H. Laustsen * \\ Department of Biotechnology and Biomedicine, Technical University of Denmark, Kongens Lyngby, DK-2800, \\ Denmark; Cecilie.Knudsen@outlook.dk \\ * Correspondence: ahola@bio.dtu.dk; Tel.: +45-2988-1134
}

Received: 27 March 2018; Accepted: 9 April 2018; Published: 15 April 2018

\begin{abstract}
With the inclusion of snakebite envenoming on the World Health Organization's list of Neglected Tropical Diseases, an incentive has been established to promote research and development effort in novel snakebite antivenom therapies. Various technological approaches are being pursued by different research groups, including the use of small molecule inhibitors against enzymatic toxins as well as peptide- and oligonucleotide-based aptamers and antibody-based biotherapeutics against both enzymatic and non-enzymatic toxins. In this article, the most recent advances in these fields are presented, and the advantages, disadvantages, and feasibility of using different toxin-neutralizing molecules are reviewed. Particular focus within small molecules is directed towards the inhibitors varespladib, batimastat, and marimastat, while in the field of antibody-based therapies, novel recombinant polyclonal plantivenom technology is discussed.
\end{abstract}

Keywords: antivenom; snakebite; small molecule toxin inhibitors; oligonucleotides; antibodies; phage display; next generation antivenom; recombinant antivenom

\section{Introduction}

Snakebite is an epidemic of the rural tropics, which annually affects over 5 million people [1]. This leads to 1.84 million cases of envenoming and upper death toll estimates of 94,000, although experts generally agree that these numbers are likely underestimated [2]. Survivors are often afflicted by psychological disorders (e.g., post-traumatic stress) and left handicapped with amputations, blindness, or other sequelae [3-7]. The situation is further complicated by antivenom shortages and the undesirable traits of some antivenoms, including immunogenicity and low efficacy [8-14]. Antivenoms from hyperimmunized animals were first envisioned by A. Calmette and C. Phisalix in 1894 [15]. Since then, antivenoms have been optimized by including various purification steps, typically involving precipitation techniques, as part of their manufacture [16]. However, despite recent reports on innovative approaches for developing a new generation of antivenoms based on biotechnological methods, medicinal chemistry, and antibody technologies [17-19], plasma-derived antivenoms of animal origin remain the only effective treatment against snakebite envenoming [20,21]. Confronted with the severity of this neglected tropical disease through a campaign led by the Global Snakebite Initiative, Health Action International, Médecins Sans Frontières, the African Society of Venimology, and the Government of Costa Rica, the World Health Organization (WHO) reinstated snakebite envenoming on its list of Category A Neglected Tropical Diseases in 2017 [22-25] and set down a working group that will develop an official strategy for prevention and treatment of snakebite envenoming [26]. With the renewed international focus on snakebite envenoming, we here provide an updated overview of the most recent advances in the development of next-generation antivenoms that are not based on conventional animal immunization schemes. This review thus focuses solely 
on developments reported after 2016, as earlier important examples have been reviewed extensively elsewhere $[17,18]$.

\section{Small Molecule Inhibitors and Peptides}

Within the field of medicinal chemistry, one interesting small molecule snake venom inhibitor to emerge recently is varespladib (Figure 1A) and the corresponding orally-available prodrug version, methyl-varespladib (Figure 1B). Varespladib previously went into clinical trials for a different indication, namely treatment of acute coronary syndrome [27], but never received approval by the US Food and Drug Administration [28,29]. A 2016 study by Lewin et al. demonstrated that nanomolar and picomolar concentrations of varespladib effectively inhibit the phospholipase $\mathrm{A}_{2}\left(\mathrm{PLA}_{2}\right)$ activities of selected snake venoms from various continents [28]. This activity against snake venom $\mathrm{PLA}_{2} \mathrm{~s}$ is highly beneficial, as members of this toxin family are often poorly immunogenic [30] and hence may invoke only a poor immune response in production animals used for conventional antivenom manufacture. A poor immune response in production animals will in turn lead to a final antivenom product with limited efficacy against PLA $_{2} \mathrm{~s}$. Mice pretreated with $4 \mathrm{mg} / \mathrm{kg}$ varespladib and subsequently envenomed with a lethal dose of Micrurus fulvius venom showed prolonged survival and reduced signs of haemorrhage [28]. This protection lasted for about $24 \mathrm{~h}$, after which the effects wore off. When $4 \mathrm{mg} / \mathrm{kg}$ varespladib and a lethal dose of Vipera berus venom were co-injected subcutaneously, varespladib succeeded in increasing survival (3 of 7 mice survived, whereas all control mice died). A similar result was obtained when varespladib was injected with a slight delay after injection of $V$. berus venom. When $8 \mathrm{mg} / \mathrm{kg}$ varespladib was administered intravenously followed by subcutaneous administration of a lethal dose of $V$. berus venom, $100 \%$ of the treated mice survived [28]. In a final experiment, a group of rats challenged with M. fulvius venom by subcutaneous injection was rescued entirely when varespladib was administered intravenously within five minutes of the envenomation. Additionally, it was shown that varespladib suppressed the venom-induced rise in PLA 2 activity and haemolysis of $M$. fulvius venom [28]. In a more recent study, varespladib was found to have a dose-dependent inhibitory effect on the PLA $\mathrm{P}_{2}$ activities of Deinagkistrodon acutus, Agkistrodon halys, Bungarus multicinctus, and Naja atra venoms in vitro [29]. At $4 \mathrm{mg} / \mathrm{kg}$, varespladib reduced the density of haemorrhagic plaques induced by $A$. halys and D. acutus venom, respectively, and decreased haemorrhage and oedema caused by all four venoms in vivo (oedema in mice treated with varespladib was decreased by $31-81 \%$ compared to control mice). Varespladib reduced the signs of venom-induced muscle damage, such as desmin degradation and serum creatine kinase levels. The $\mathrm{ED}_{50} \mathrm{~s}$ for inhibition of lethality demonstrated that varespladib more effectively inhibited the viperid venoms of $D$. acutus $\left(\mathrm{ED}_{50} 1.14 \mu \mathrm{g} / \mathrm{g}\right.$ ) and A. halys ( $\mathrm{ED}_{50} 0.45 \mu \mathrm{g} / \mathrm{mg}$ ) compared to the elapid venoms of B. multicinctus $\left(\mathrm{ED}_{50} 15.23 \mu \mathrm{g} / \mathrm{g}\right)$ and N. atra $\left(\mathrm{ED}_{50} 22.09 \mu \mathrm{g} / \mathrm{mg}\right)$ [29]. It could be speculated that this is due to differences in $\mathrm{PLA}_{2}$ abundance or $\mathrm{PLA}_{2}$ subtypes between viperid and elapid venoms. As many snake venoms contain toxins (particularly from the PLA $\mathrm{A}_{2}$ family) that exert their actions in synergy with other toxins and venom components [31], it could also be speculated that varespladib for certain snake venoms could interfere with important toxin synergisms leading to an inhibition of overall venom toxicity. However, not all snake venoms rely extensively on $\mathrm{PLA}_{2} \mathrm{~s}$. Thus, a natural limitation exists for the usefulness of the drug. As an example, venom from the Dendroaspis genus is almost entirely devoid of $\mathrm{PLA}_{2} \mathrm{~s}$ [32-34], and it is unlikely that varespladib would be useful against bites inflicted by snakes of this genus. Nevertheless, while varespladib in itself may have interesting applications, its corresponding prodrug, methyl-varespladib, can be formulated for oral administration, making it a potential first line of defence. As such, alone or in combination with other drugs, methyl-varespladib might be able to buy snakebite victims the time needed to reach appropriate treatment facilities, where additional antivenom treatment can be provided. Such an application warrants further studies of absorption and bioavailability subsequent to oral administration. 

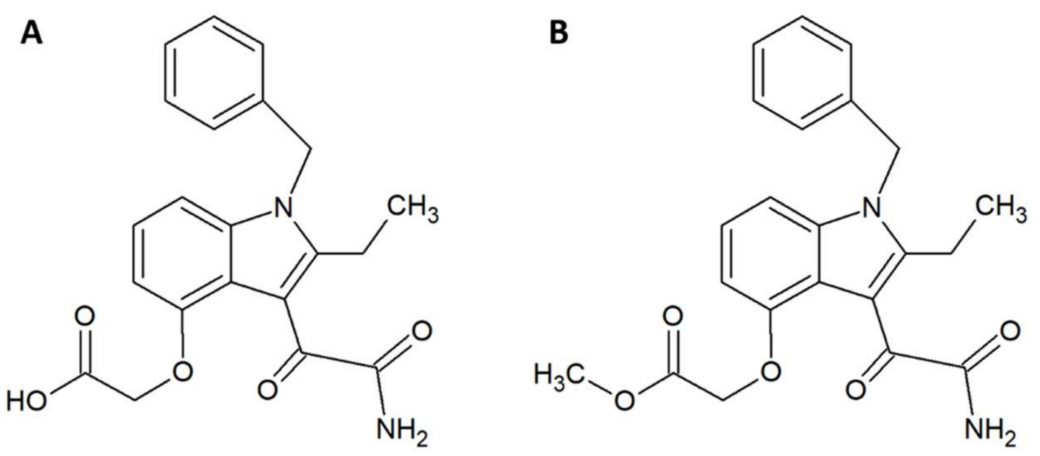

Figure 1. Chemical structures of (A) varespladib and (B) methyl-varespladib.

Other examples of promising small molecule inhibitors include the matrix metalloproteinase inhibitors batimastat (Figure 2A) and marimastat (Figure 2B) [35,36]. In a study by Arias et al., $200 \mu \mathrm{M}$ of these molecules were incubated with $4 \mathrm{LD}_{50} \mathrm{~s}$ of Echis ocellatus venom and co-injected into the tail vein of CD-1 mice [37]. The molecules prolonged survival, but did not provide full protection. Nevertheless, administration of batimastat inhibited the haemorrhagic $\left(\mathrm{IC}_{50}=30 \mu \mathrm{M}\right)$, in vitro coagulant $\left(\mathrm{IC}_{50}=0.05 \mu \mathrm{M}\right)$, proteinase $\left(\mathrm{IC}_{50}=2.6 \mu \mathrm{M}\right)$, and defibrinogenating $\left(\mathrm{IC}_{50}=200 \mu \mathrm{M}\right)$ activities of the venom from an E. ocellatus specimen from Cameroon. $\mathrm{IC}_{50} \mathrm{~s}$ for E. ocellatus venom from a specimen from Ghana were also determined; however, these vary somewhat from the values reported for the specimen from Cameroon. Fast administration of batimastat resulted in increased inhibition of haemorrhage. On the other hand, a delay in administration led to greater inhibition of defibrinogenation, which could be completely inhibited by a 60-min-delayed injection of $200 \mu \mathrm{L}$ of $500 \mu \mathrm{M}$ batimastat. Batimastat was more effective in inhibiting haemorrhagic activity than marimastat, and conversely marimastat was better at inhibiting defibrinogenating activity than batimastat. Five hundred micromoles of batimastat provided full protection against $1.5 \mathrm{LD}_{50}$ of $E$. ocellatus venom when the venom was injected intramuscularly immediately followed by an intramuscular administration of batimastat. With a delay of 15-60 min in administration, batimastat no longer provided full protection, although it still prolonged survival [37]. Both compounds contain hydroxamate groups, which might by hydrolysed in plasma [38]. However, batimastat and marimastat have previously been investigated as potential cancer drugs. One study found that the half-life of batimastat was 19.1 days after intraperitoneal injection in humans (batimastat is not orally available) [39], and another study found that the half-life of marimastat after oral administration in

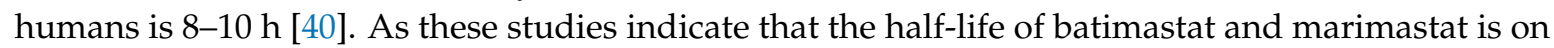
par with existing antivenoms, these small molecule inhibitors seem to be promising as supplements to existing antivenoms.

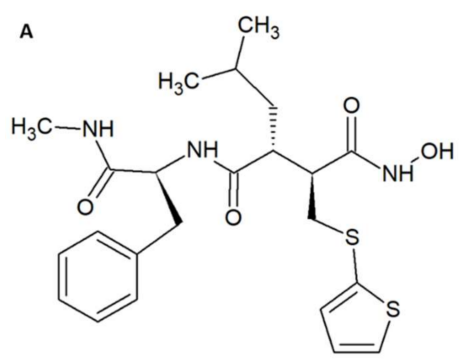<smiles>CNC(=O)C(NC(=O)[C@@H](CC(C)C)[C@H](O)C(=O)NO)C(C)(C)C</smiles>

Figure 2. Chemical structures of (A) batimastat. (B) marimastat.

In a different study, Ferreira et al. utilised a combination of in vitro, in silico, and in vivo experiments in an attempt to design, synthesise, and evaluate enzyme inhibitors that could be used as fortifying supplements for antivenoms [41]. The rational design strategy for the small molecule enzyme 
inhibitors employed available sequence data on the metalloproteinase BpMP-I from Bothrops pauloensis and the crystal structure of the homologous BaP-I from Bothrops asper to create a three-dimensional (3D) model of BpMP-1, which was used to create a docking model for the inhibitors. Since these toxins are dependent on zinc ions, molecules containing zinc-chelating groups were generated and tested for their ability to inhibit the metalloproteinase in an azocasein assay [41]. Based on these results and the predicted docking geometries of these molecules and the toxin BpMP-I, two improved versions (5A and $5 \mathrm{~B}$ ) of the most promising molecule (2B) were designed (Figure 3). These were synthesised and once again evaluated in an azocasein assay. The two modified molecules were 38 and 1700 times more active than the original inhibitor, respectively, with $\mathrm{IC}_{50} \mathrm{~s}$ of $78.12 \mu \mathrm{M}$ and $1.77 \mu \mathrm{M}$. These improved compounds also decreased haemorrhagic activity in vivo. Incubation of $5 \mathrm{~B}$ with whole venom from $B$. pauloensis 1:10 ( $w / w)$ (venom-to-inhibitor) followed by injection into mice completely reduced the haemorrhagic halo in the mice. If the venom was administered $10 \mathrm{~min}$ before the inhibitor, the haemorrhagic halo was, however, only reduced by $31 \%$. Bioinformatic models predicted that the molecules possibly bind quite well to different snake venom metalloproteinases (SVMPs), although this was not explored experimentally. Finally, it was demonstrated that compound $5 B$ interacts with $\mathrm{Zn}^{2+}$, which likely explains its inhibiting activity on $\mathrm{Zn}^{2+}$-dependent metalloproteinases [41].<smiles>COc1ccc(/C=N/NC(N)=S)cc1</smiles>

Figure 3. Chemical structures of (A) compound ' $2 B$ '. (B) compound ' $5 A^{\prime}$ '. (C) compound ' $5 \mathrm{~B}$ '.

Using a phage display approach, preliminary work on toxin-neutralizing peptides has also been reported [42]. Here, smaller peptides of varying lengths were first discovered using synthetic peptide phage display libraries, after which they were synthetized and tested for binding ability to their target toxin and related homologs. Peptide binders were discovered for a dendrotoxin from Dendroaspis polylepis, myotoxin II from B. asper, and $\alpha$-cobratoxin from Naja kaouthia. For peptide 33535 , a $\mathrm{K}_{\mathrm{d}}$ was determined to $20 \mu \mathrm{M}$ and truncated versions of this peptide (peptide 7 and peptide 8) were synthesised, which demonstrated comparable binding ability in a competitive ELISA setup [42]. No results on in vivo efficacy have, however, been reported.

Using one of the same peptide phage display libraries as Laustsen [42], Titus et al. employed phage display to find binders for a consensus $\mathrm{PLA}_{2}$ [43]. The PLA $\mathrm{P}_{2}$ was based on a consensus sequence derived from alignments of available sequences of Agkistrodon $\mathrm{PLA}_{2} \mathrm{~S}$ and mapped to an Agkistrodon piscivorus piscivorus PLA $_{2}$ structure before being synthesised. Titus et al. selected binders capable of inhibiting Agkistrodon piscivorus leucostoma PLA $_{2}$ activity in vitro as assessed by an EnzChek phospholipase $A_{2}$ assay (Invitrogen). The four most promising binders inhibited 30-60\% of the $\mathrm{PLA}_{2}$ activity. One of these binders was further tested against venom from A. p. leucostoma (again), Crotalus adamanteus, Crotalus atrox, Crotalus scutulatus, and Agkistrodon contortrix laticinctus using the same assay. Inhibition of $\mathrm{PLA}_{2}$ activities of these venoms was, however, only $30-40 \%$ [43], which leaves much room for improvement. Given that linear peptides typically have a poor half-life, much more work is needed before any analogues of the reported peptides may become as promising as varespladib.

Nanoparticles represent another technical avenue that could lead to the development of therapeutics that inhibit the activities of snake venom components. In one noteworthy study by Karain et al. [44], $4 \mu \mathrm{g} / \mathrm{g}$ of the nanoparticle C60 fullerene (Figure 4) prolonged survival of Acheta domesticus specimens (crickets) envenomed with Crotalus oreganushelleri venom. Twenty-four 
hours after injection, crickets that were administered the C60 fullerene, followed by administration of venom, had an average survival rate that was 15.7\% higher than that of controls not receiving the C60 fullerene. After $48 \mathrm{~h}$, the average survival rate was $25.0 \%$ higher [44]. These results warrant further studies in mammalian models. The C60 fullerene possesses several qualities desirable in an antivenom supplement, such as being cheap, stable, and having a great volume of distribution. However, the fact that it cannot be given intravenously due to its hydrophobicity and must be given orally or injected intraperitoneally dissolved in olive oil or a similar vehicle decreases its immediate usefulness for treatment of envenoming and affects its pharmacokinetics. While C60 becomes detectable almost instantly in the blood, it still takes $8 \mathrm{~h}$ for it to reach maximal concentration when administered orally in rats [44]. This could prove problematic in the case of fast-acting venoms and makes C60 less readily applicable for snakebite treatment.

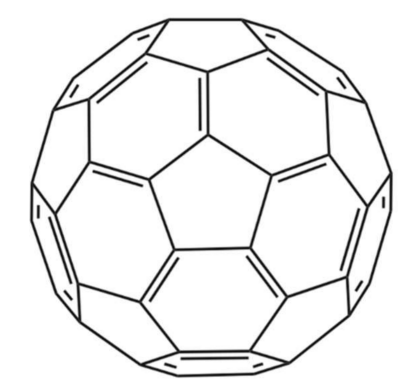

Figure 4. Chemical structure of the C60 fullerene [45].

Similar to Ferreira et al. [41], O'brien and colleagues [46] chose to follow an approach of rationally designing, synthesising, and evaluating a molecule capable of neutralising venom activities. They synthesised various nanoparticles from different mixtures of four components and tested their abilities to neutralize the PLA 2 activity of whole venoms from Bungarus caerulus, Naja mossambica, and Apis mellifera (Figure 5). The goal was to find a nanoparticle capable of broadly neutralising the effects of $\mathrm{PLA}_{2}$ s from various snake venoms. Using this approach, the authors developed a on-cytotoxic nanoparticle with long dissociation rates for $\mathrm{PLA}_{2} \mathrm{~S}$. This nanoparticle is devoid of phospholipids and does therefore not act as a substrate for $\mathrm{PLA}_{2} \mathrm{~s}$. Instead, results indicate that the nanoparticle exerts its function by interacting directly with $\mathrm{PLA}_{2} \mathrm{~S}$ rather than with lysophosphatidylcholine (a product of $\mathrm{PLA}_{2}$ activity responsible for inducing haemolysis) [46]. It should, however, be noted that such nanoparticles have never been tested in vivo, and it is unknown whether their in vitro efficacy will translate well into a preclinical setting.
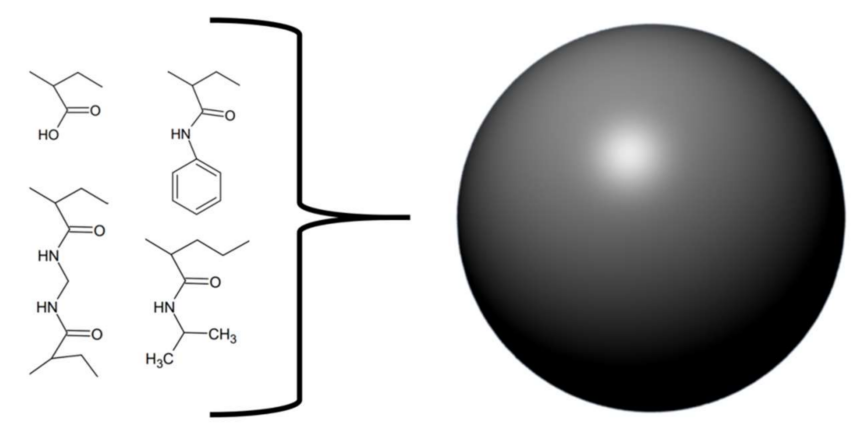

Figure 5. Schematic overview of the molecular components used by O'Brien et al. [46] to assemble the nanoparticles.

A trend within the studies showcased here is the focus on enzyme inhibitors. Seeing as many toxins belong to the same enzymatic protein families (e.g., snake venom metalloproteinases, 
serine proteinases, and $\mathrm{PLA}_{2} \mathrm{~s}$ ), and since these toxic enzymes share very similar substrates within these families, the strategy of targeting enzymatic activity with a substrate mimetic seems logical. Most enzymes have catalytic clefts, which are feasible targets for engineered and naturally occurring inhibitors. Hence, it is unsurprising that much prior work was focused exactly on inhibition of enzymatic toxins [17].

\section{Oligonucleotides and Antibodies}

Although the main work was performed on a cone snail toxin, and not a snake toxin, another approach to developing novel compounds for snakebite envenoming therapy focuses on the use of oligonucleotide-based aptamers, which have found various applications, including in therapeutics [47]. In 2017, El-Aziz and colleagues published an article arguing for favourable characteristics of oligonucleotides, including low immunogenicity, small size, thermal stability, biocompatibility, and standardised production methods [48]. Oligonucleotides are devoid of many of the drawbacks associated with antibody production by immunisation (e.g., use of production animals, long production time, poor immunogenicity of many smaller toxins, and cost of production) and with the treatment itself (e.g., immunogenicity of animal-derived antibodies, limited shelf-life, need for refrigeration, and potential lack of specificity). On this basis, El-Aziz et al. sought to find an oligonucleotide capable of neutralising the activity of the $\alpha \mathrm{C}$-conotoxin PrXA from the cone snail species, Conus parius. One of the tested oligonucleotides proved capable of inhibiting the activity of $\alpha \mathrm{C}$-conotoxin PrXA in vitro, but at the tested doses (0-0.25 $\mu \mathrm{g}$ oligonucleotide/g mouse bodyweight) could only provide prolonged survival in vivo and not full protection. When administered at higher concentrations, the oligonucleotide did, however, provide full protection in vivo. The $\mathrm{ED}_{50}$ against lethality for the oligonucleotide was determined to be $0.18 \mu \mathrm{g} / \mathrm{g}$ mouse bodyweight when administered intraperitoneally, and $0.22 \mu \mathrm{g} / \mathrm{g}$ mouse bodyweight when administered subcutaneously. As the oligonucleotide was unable to inhibit a different blocker (waglerin) of the muscle nicotinic acetylcholine receptor targeted by the conotoxin, the oligonucleotide was assumed to be specific for $\alpha \mathrm{C}$-conotoxin PrXa [48]. Another benefit of working with oligonucleotides in the lab setting includes the low cost of small-scale synthesis for research and development (R\&D) purposes, which makes it easy for researchers to quickly evaluate a large range of molecules at limited cost. However, before evaluating the use of oligonucleotides in the clinical setting, more studies evaluating their cost of manufacture in larger scale are needed.

In the field of recombinant antivenoms, attention to the use of camelid $\mathrm{V}_{\mathrm{H}} \mathrm{Hs}$ (also known as nanobodies) as therapeutic agents has increased. This is likely due to their stability (thermal, chemical, $\mathrm{pH}$ ), solubility, high target specificity and affinity, and good expression levels in prokaryotic expression systems, which make them attractive as therapeutic molecules for the treatment of envenomation $[49,50]$. Due to their small size, $\mathrm{V}_{\mathrm{H}} \mathrm{Hs}$ have a relatively large volume of distribution, but they have been shown to have relatively short half-lives in vivo. Recent advances within the development of recombinant antivenoms includes a study by Anderson et al., in which the authors set out to improve the stability of two $\mathrm{V}_{\mathrm{H}} \mathrm{Hs}$ by making them more heat-resistant [51]. The suboptimal thermal stability of existing antivenoms is currently compensated for by using cold-chain transportation and storage. The necessity of a cold chain is both costly and may be outright unavailable in certain regions. Lyophilisation of antivenom is a commonly used alternative to cold chains but can potentially lead to protein denaturation and prolonged time to treatment as the antivenom must be reconstituted before use. Improved thermal stability might negate this need for a cold chain and lyophilisation of antivenoms [51]. The starting points of Anderson's study were the $\mathrm{V}_{\mathrm{H}} \mathrm{Hs} \mathrm{C} 2$ and $\mathrm{C} 20$, which had a previously-demonstrated ability to neutralize the toxic effects caused by $\alpha$-cobratoxin from $N$. kaouthia venom [51,52]. The authors introduced mutations known to enhance the thermal stability of $\mathrm{V}_{\mathrm{H}} \mathrm{Hs}$ and further introduced an additional disulphide bridge in each antibody (also known generally to lead to increased stability) (Figure 6). With one exception, all mutated binders retained the affinities for $\alpha$-cobratoxin of the original binders. Additionally, refolding and retention of 
activity after thermal stress was improved for all mutants. For the C20 mutants, aggregation due to thermal stress was also decreased. Finally, the melting temperatures were improved from $71^{\circ} \mathrm{C}$ for $\mathrm{C} 2$ to $86^{\circ} \mathrm{C}$ for the best $\mathrm{C} 2$ mutant, and from $60{ }^{\circ} \mathrm{C}$ for $\mathrm{C} 20$ to $75^{\circ} \mathrm{C}$ for the best $\mathrm{C} 20$ mutant [51].

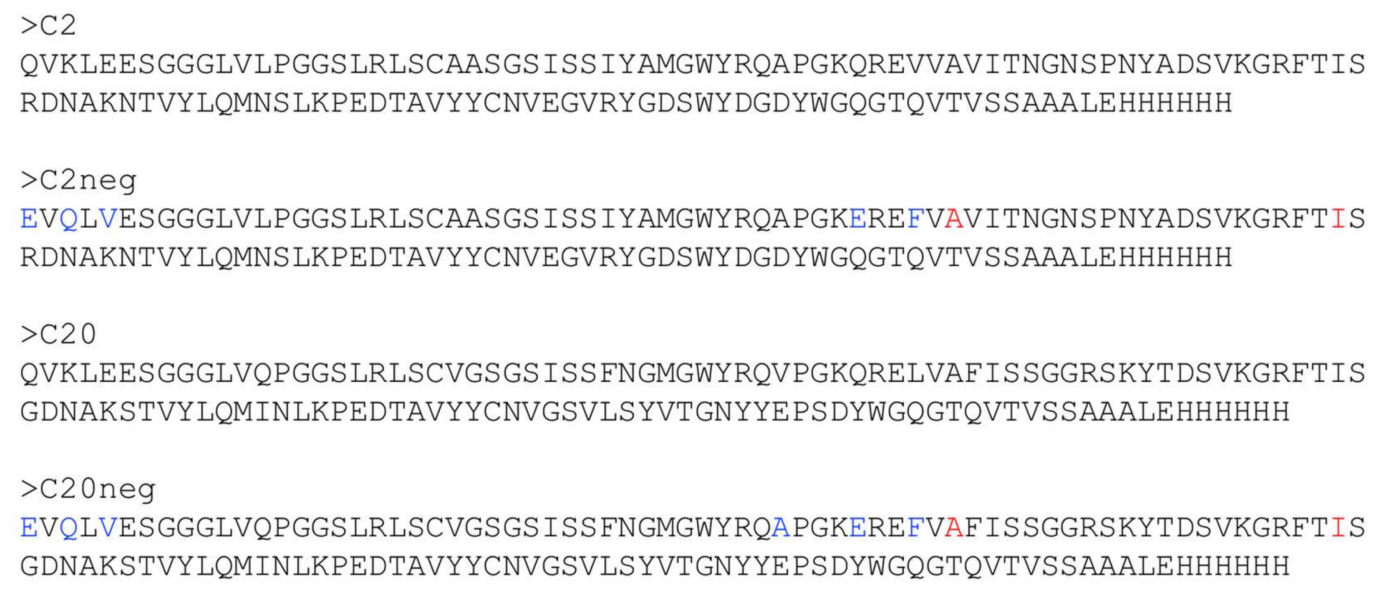

Figure 6. Overview of mutations introduced in $\mathrm{V}_{\mathrm{H}} \mathrm{Hs}$ by Anderson et al. to improve the thermal stability of the C2 and C20 nanobodies [51]. The sequences of the wild-type antibodies C2 and C20 are shown. The sequences of the mutated C2neg and C20neg antibodies are also shown, with mutations highlighted in blue. Finally, C2neg and C20neg were further mutated by the introduction of additional disulphide bridges to form $\mathrm{C} 2 \mathrm{neg}+$ and $\mathrm{C} 20 \mathrm{neg}+$. This was accomplished by mutating the amino acids highlighted in red into cysteines. Adapted with the author's permission.

Other efforts within the field of recombinant antivenom are aimed at optimizing the production rather than the stability of antivenoms. One such effort is reported by Julve Parreño et al., who explored the possibility of producing so-called 'plantivenoms' [53]. The researchers used in planta production of polyclonal antibodies derived from $\mathrm{V}_{\mathrm{H}} \mathrm{H}$ sequences of dromedaries immunised with mixtures of venoms from Crotalus simus, C. scutulatus, and B. asper. This was accomplished by the insertion of dromedary $\mathrm{V}_{\mathrm{H}} \mathrm{H}$ sequences into a genetically-modified vector derived from tobacco mosaic virus, which was subsequently used to infect Nicotiana benthamiana specimens via Agrobacterium tumefaciens bacteria and stimulate antibody production. The authors demonstrated that the results were reproducible and that the plantibodies proved to be capable of binding venom components from C. simus, C. scutulatus, and B. asper venoms, but not venom components of Naja nubiae and N. mossambica venom. To further improve their plantibodies, the researchers employed phage display technology to select the best $B$. asper $\mathrm{V}_{\mathrm{H}} \mathrm{H}$ binders against four different venom fractions, representing the four most important toxin families in this venom. The 36 most promising $\mathrm{V}_{\mathrm{H}} \mathrm{H}$ binders were selected and converted into chimeric antibodies composed of the human IgG constant regions of the heavy chains and the $\mathrm{V}_{\mathrm{H}} \mathrm{Hs}$ (Figure 7). This optimized oligoclonal plantivenom showed a similar binding pattern to the existing B. asper antivenom and could neutralise the haemorrhagic, PLA 2 , proteinase, and lethal activities of $B$. asper venom, but not the in vitro coagulant activity. However, the equine-derived B. asper antivenom used as a control had a superior efficacy, as demonstrated by their respective ED50s (neutralisation of lethality: $3.1 \mathrm{mg}$ antivenom/ $\mathrm{mg}$ venom versus $43.2 \mathrm{mg}$ plantivenom $/ \mathrm{mg}$ venom) [53]. Under the given experimental conditions, the plantivenom successfully prevented lethality in all mice at a dose of $61.24 \mathrm{mg}$ plantivenom $/ \mathrm{mg}$ venom. While improvements are needed to increase the plantivenom's titer and neutralizing capacity of the coagulant activity of $B$. asper venom to become on par with existing antivenoms, this study clearly demonstrates promising results for a highly innovative approach to antivenom development. 


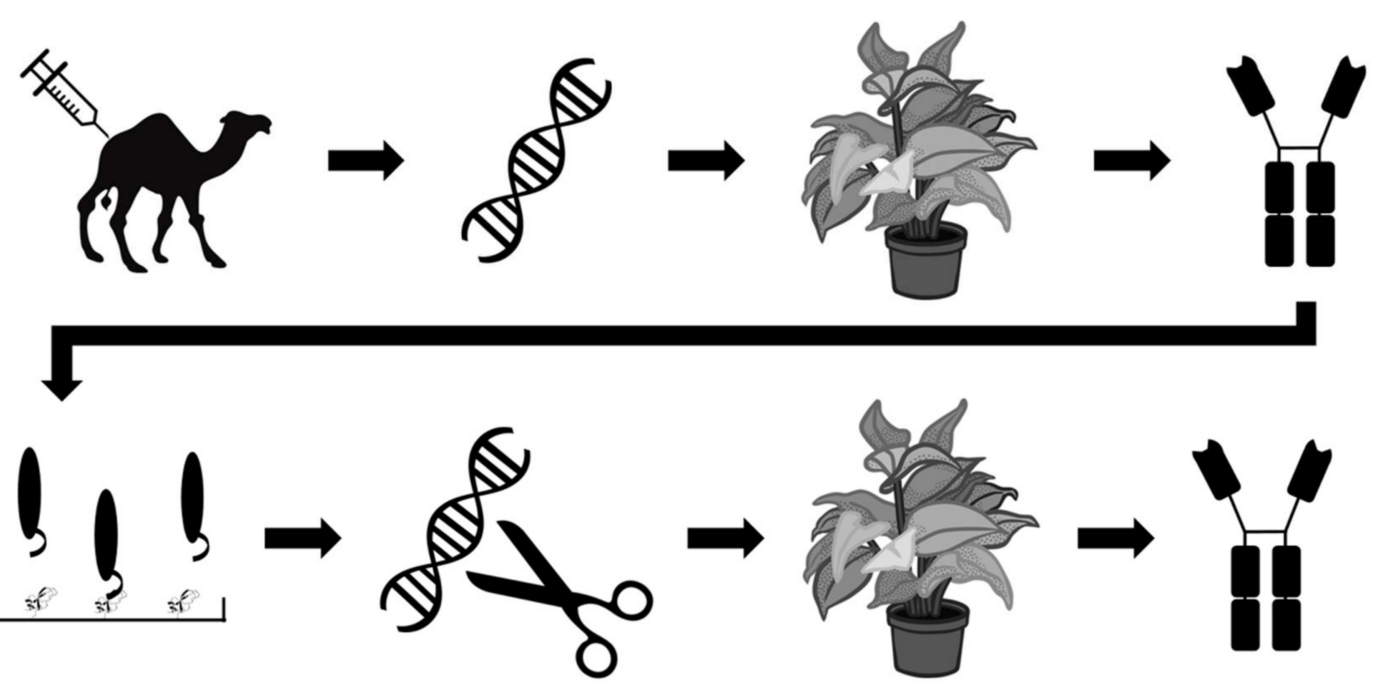

Figure 7. Schematic overview of the strategy employed by Julve Parreño et al. [53]. Dromedaries were immunised with a mixture of venoms. $\mathrm{V}_{\mathrm{H}} \mathrm{H}$ sequences were extracted from the immunised animals, cloned into a viral vector, and used to infect Nicotiana benthamiana specimens. The plant-expressed $\mathrm{V}_{\mathrm{H}} \mathrm{Hs}$ were evaluated in vivo and subjected to phage display experiments involving four venom fractions from Bothrops asper (representing the four important major toxin families of this venom) to accumulate high affinity $\mathrm{V}_{\mathrm{H}} \mathrm{Hs}$. The 36 best $\mathrm{V}_{\mathrm{H}} \mathrm{H}$ binders were converted to human-dromedary chimeric antibodies, which were expressed in N. benthamiana as well and tested in vivo.

Julve Parreño et al. claim that in planta production may serve as a cost-effective alternative to conventional antivenom manufacture and even to the manufacturing of recombinant monoclonal antibodies [53]. However, the researchers do not provide comprehensive argumentation for their cost evaluations, and such viewpoints therefore deserve further scrutiny. The drawbacks of plants as expression systems for animal/human antibodies particularly include low protein yields, non-human glycosylation patterns, and the need for isolating and purifying the antibodies from the rigid plant matrix, which is high in cellulose, lignin, and other polymeric macromolecules. The authors achieved a yield of $0.2 \mathrm{~g}$ antibodies per $\mathrm{kg}$ of plant leaves [53], which is indeed impressive, as limited efforts had been applied to optimising expression. However, this does not compare favourably with standardised mammalian cell cultivation approaches, which routinely achieve yields of $5 \mathrm{~g} / \mathrm{L}$ of correctly folded and secreted IgGs [20], with exceptional examples even reaching $27 \mathrm{~g} / \mathrm{L}$ [54]. Julve Parreño et al. also argue that the production of oligoclonal antibody mixtures by parallel batch expression is not economically feasible without compromising efficacy, as many antibodies are needed to target the large arsenal of toxins present in snake venoms [53]. In itself, this statement may not be incorrect. However, with the recent introduction of oligoclonal expression systems for chinese hamster ovary $(\mathrm{CHO})$ cells [55-57], cost simulations for the manufacture of oligoclonal antibody mixtures recombinantly expressed by mammalian cells in a single-batch setup demonstrate that such mixtures can be produced cost-competitively compared to current antivenom manufacture [58,59]. In planta expression of antibody mixtures may therefore very well serve an important purpose within development. Yet it remains to be seen whether this approach is in fact economically attractive. A flag should at least be raised, given that no antibody-based therapy relying on in planta expression has ever entered the market [60] and previous attempts to bring the Ebola therapeutic, ZMapp (consisting of three human IgGs originally expressed in N. benthamiana) [61,62], to the clinic encountered scale up and manufacturing challenges with the plant-based expression system.

The field of human antibody fragments has for many years been championed by groups from Brazil and Mexico [63-70]. In this field, Silva et al. reported the use of phage display technology to select human scFvs against components from the venoms of Crotalus durissus terrificus and 
Bothrops jararacussu [71]. Based on an ELISA screening approach, three of these scFvs (B7, C11, and E9) were selected due to their cross-reactivity to components in both venoms. The researchers demonstrated that the scFvs were capable of neutralising the haemolytic and plasma-clotting activities of crotalic and bothropic venoms to different extents, and that the scFvs had the greatest effect on venom activity when they were used in combination. Haemolytic activity was fully inhibited by the combination of scFvs, while plasma-clotting was decreased but not fully prevented. Furthermore, the scFvs prolonged the survival of envenomed mice at ratios of $1: 1(w / w)$, but were maximally able to provide protection against lethality for $25 \%$ of the mice [71]. More research is thus needed to discover and engineer such human scFvs to gain improved efficacy.

\section{Conclusions and Perspectives}

Renewed interest in snakebite envenoming from international organisations, such as the WHO, could contribute to spreading awareness of this neglected tropical disease and facilitate increased research efforts and the development of new treatments. Current trends in such efforts include the investigation of the utility of several small molecule inhibitors, which are currently being evaluated for their ability to neutralise the effects of enzymatic toxins. Perhaps the most promising of these small molecule inhibitors, varespladib, may have the potential to become a broad-spectrum orally

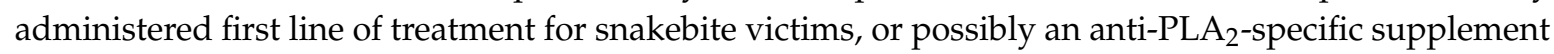
to conventional antivenom therapy. While small molecule inhibitors might be particularly well-suited for targeting enzymatic toxins, such as $\mathrm{PLA}_{2} \mathrm{~S}$ and proteinases, smaller non-enzymatic toxins (such as three-finger toxins) may better be targeted by antibody-based or antibody-like therapeutics. It is therefore likely that increased research efforts on nanobodies and human antibody formats will occur within the next few years. This not only represents an opportunity for innovation within snakebite antivenoms, but it may also facilitate more research efforts on the development of therapies against envenomings by other animals, such as scorpions and spiders.

Acknowledgments: Thanks go to the Novo Nordisk Foundation for financial support (NNF16OC0019248). We would also like to thank C. M. Kiel and J. A. Jürgensen for proofreading the manuscript prior to submission.

Author Contributions: Both authors contributed equally to the writing of this paper.

Conflicts of Interest: The authors declare no conflict of interest.

\section{References}

1. Chippaux, J.-P. Snake-bites: Appraisal of the global situation. WHO Bull. OMS 1998, 76, 515-524.

2. Kasturiratne, A.; Wickremasinghe, A.R.; De Silva, N.; Gunawardena, N.K.; Pathmeswaran, A.; Premaratna, R.; Savioli, L.; Lalloo, D.G.; De Silva, H.J. The global burden of snakebite: A literature analysis and modelling based on regional estimates of envenoming and deaths. PLoS Med. 2008, 5, 1591-1604. [CrossRef] [PubMed]

3. Chippaux, J.P. Estimate of the burden of snakebites in sub-Saharan Africa: A meta-analytic approach. Toxicon 2011, 57, 586-599. [CrossRef] [PubMed]

4. Mello, L.F.; Barcelos, M.G.; Meohas, W.; Pinto, L.W.; Melo, P.A.; Nogueira Neto, N.C.; Smith, J. Chronic ulceration of the leg following extensive scarring due to a snake bite complicated by squamous cell carcinoma. Skelet. Radiol. 2000, 29, 298-301. [CrossRef]

5. Smith, J.; Mello, L.F.B.; Nogueira Neto, N.C.; Meohas, W.; Pinto, L.W.; Campos, V.A.; Barcellos, M.G.; Fiod, N.J.; Rezende, J.F.N.; Cabral, C.E.L. Malignancy in chronic ulcers and scars of the leg (Marjolin's ulcer): A study of 21 patients. Skelet. Radiol. 2001, 30,331-337. [CrossRef]

6. Warrell, D.A.; Ormerod, L.D. Snake venom ophthalmia and blindness caused by the spitting cobra (Naja nigricollis) in Nigeria. Am. J. Trop. Med. Hyg. 1976, 25, 525-529. [CrossRef] [PubMed]

7. Williams, S.S.; Wijesinghe, C.A.; Jayamanne, S.F.; Buckley, N.A.; Dawson, A.H.; Lalloo, D.G.; de Silva, H.J. Delayed psychological morbidity associated with snakebite envenoming. PLoS Negl. Trop. Dis. 2011, 5, e1255. [CrossRef] [PubMed]

8. Theakston, R.; Warrell, D. Crisis in snake antivenom supply for Africa. Lancet 2000, 356, 2104. [CrossRef] 
9. Williams, D.J.; Gutiérrez, J.; Calvete, J.J.; Wüster, W.; Ratanabanangkoon, K.; Paiva, O.; Brown, N.I.; Casewell, N.R.; Harrison, R.A.; Rowley, P.D.; et al. Ending the drought: New strategies for improving the flow of affordable, effective antivenoms in Asia and Africa. J. Proteom. 2011, 74, 1735-1767. [CrossRef] [PubMed]

10. Ariaratnam, C.A.; Sjostrom, L.; Raziek, Z.; Kularatne, S.A.; Arachchi, R.W.K. Kodikara Sheriff, M.H.R.; Theakston, R.D.G.; Warrell, D.A. An open, randomized comparative trial of two antivenoms for the treatment of envenoming by Sri Lankan Russell' s viper (Daboia russelii). Trans. R. Soc. Trop. Med. Hyg. 2001, 95, 74-80. [CrossRef]

11. León, G.; Monge, M.; Rojas, E.; Lomonte, B.; Gutiérrez, J.M. Comparison between IgG and F(ab' $) 2$ polyvalent antivenoms: Neutralization of systemic effects induced by Bothrops asper venom in mice, extravasation to muscle tissue, and potential for induction of adverse reactions. Toxicon 2001, 39, 793-801. [CrossRef]

12. Herrera, M.; León, G.; Segura, A.; Meneses, F.; Lomonte, B.; Chippaux, J.P.; Gutiérrez, J.M. Factors associated with adverse reactions induced by caprylic acid-fractionated whole IgG preparations: Comparison between horse, sheep and camel IgGs. Toxicon 2005, 46, 775-781. [CrossRef] [PubMed]

13. Visser, L.E.; Kyei-Faried, S.; Belcher, D.W.; Geelhoed, D.W.; van Leeuwen, J.S.; van Roosmalen, J. Failure of a new antivenom to treat Echis ocellatus snake bite in rural Ghana: The importance of quality surveillance. Trans. R. Soc. Trop. Med. Hyg. 2008, 102, 445-450. [CrossRef] [PubMed]

14. Calvete, J.J.; Arias, A.S.; Rodríguez, Y.; Quesada-Bernat, S.; Sánchez, L.V.; Chippaux, J.P.; Pla, D.; Gutiérrez, J.M. Preclinical evaluation of three polyspecific antivenoms against the venom of Echis ocellatus: Neutralization of toxic activities and antivenomics. Toxicon 2016, 119, 280-288. [CrossRef] [PubMed]

15. Bochner, R. Paths to the discovery of antivenom serotherapy in France. J. Venom. Anim. Toxins Incl. Trop. Dis. 2016, 22, 1-7. [CrossRef] [PubMed]

16. Chippaux, J.P. WHO guidelines for the production, control and regulation of snake antivenom immunoglobulins. Biol. Aujourdhui 2010, 204, 87-91. [CrossRef] [PubMed]

17. Laustsen, A.H.; Engmark, M.; Milbo, C.; Johannesen, J.; Lomonte, B.; Gutiérrez, J.M.; Lohse, B. From fangs to pharmacology: The future of antivenoms. Curr. Pharm. Des. 2016, 9, 5270-5293. [CrossRef]

18. Laustsen, A.H.; Solà, M.; Jappe, E.C.; Oscoz, S.; Lauridsen, L.P.; Engmark, M. Biotechnological trends in spider and scorpion antivenom development. Toxins (Basel) 2016, 8, 226. [CrossRef] [PubMed]

19. Laustsen, A.H. Guiding recombinant antivenom development by omics technologies. N. Biotechnol. 2017. [CrossRef] [PubMed]

20. Laustsen, A.H.; Gutiérrez, J.M.; Knudsen, C.; Johansen, K.H.; Méndez, E.B.; Cerni, F.A.; Jürgensen, J.A.; Øhlenschlæger, M.; Ledsgaard, L.; Esteban, A.M.; et al. Pros and cons of different therapeutic antibody formats for recombinant antivenom development. Toxicon 2018. [CrossRef] [PubMed]

21. Gutiérrez, J.M.; León, G.; Lomonte, B.; Angulo, Y. Antivenoms for snakebite envenomings. Inflamm. Allergy Drug Targets 2011, 10, 369-380. [CrossRef] [PubMed]

22. Chippaux, J.P. Snakebite envenomation turns again into a neglected tropical disease! J. Venom. Anim. Toxins Incl. Trop. Dis. 2017, 23, 1-2. [CrossRef] [PubMed]

23. Rägo, L.; Marroquin, A.M.P.; Nübling, C.M.; Sawyer, J. Treating snake bites-A call for partnership. Lancet 2015, 386, 2252. [CrossRef]

24. Williams, D.J. Snake bite: A global failure to act costs thousands of lives each year. BMJ 2015, 351, h5378. [CrossRef] [PubMed]

25. Alirol, E.; Lechevalier, P.; Zamatto, F.; Chappuis, F.; Alcoba, G.; Potet, J. Antivenoms for snakebite envenoming: What is in the research pipeline? PLoS Negl. Trop. Dis. 2015, 9, e0003896. [CrossRef] [PubMed]

26. Word Health Organization WHO Working Group on Snakebite Envenoming. Available online: http:// www.who.int/snakebites/control/WHO_Working_Group_on_Snakebite_Envenoming/en/ (accessed on 8 April 2018).

27. U.S. National Library of Medicine Vista-16 trial: Evaluation of Safety and Efficacy of Short-term A-002 Treatment in Subjects With Acute Coronary Syndrome. Available online: https://clinicaltrials.gov/ct2/ show / NCT01130246 (accessed on 8 April 2018).

28. Lewin, M.; Samuel, S.; Merkel, J.; Bickler, P. Varespladib (LY315920) appears to be a potent, broad-spectrum, inhibitor of snake venom phospholipase A2 and a possible pre-referral treatment for envenomation. Toxins (Basel) 2016, 8, 248. [CrossRef] [PubMed] 
29. Wang, Y.; Zhang, J.; Zhang, D.; Xiao, H.; Xiong, S.; Huang, C. exploration of the inhibitory potential of varespladib for snakebite envenomation. Molecules 2018, 23, 391. [CrossRef] [PubMed]

30. Laustsen, A.H.; Engmark, M.; Clouser, C.; Timberlake, S.; Vigneault, F.; Gutiérrez, J.M.; Lomonte, B. Exploration of immunoglobulin transcriptomes from mice immunized with three-finger toxins and phospholipases $\mathrm{A}_{2}$ from the Central American coral snake, Micrurus nigrocinctus. Peer J 2017, 5, e2924. [CrossRef] [PubMed]

31. Laustsen, A.H. Toxin synergism in snake venoms. Toxin Rev. 2016, 35, 165-170. [CrossRef]

32. Laustsen, A.H.; Lomonte, B.; Lohse, B.; Fernández, J.; Gutiérrez, J.M. Unveiling the nature of black mamba (Dendroaspis polylepis) venom through venomics and antivenom immunoprofiling: Identification of key toxin targets for antivenom development. J. Proteom. 2015, 119, 126-142. [CrossRef] [PubMed]

33. Lauridsen, L.P.; Laustsen, A.H.; Lomonte, B.; Gutiérrez, J.M. Toxicovenomics and antivenom profiling of the eastern green mamba snake (Dendroaspis angusticeps). J. Proteom. 2016, 136, 248-261. [CrossRef] [PubMed]

34. Ainsworth, S.; Petras, D.; Engmark, M.; Süssmuth, R.D.; Whiteley, G.; Albulescu, L.O.; Kazandjian, T.D.; Wagstaff, S.C.; Rowley, P.; Wüster, W.; et al. The medical threat of mamba envenoming in sub-Saharan Africa revealed by genus-wide analysis of venom composition, toxicity and antivenomics profiling of available antivenoms. J. Proteom. 2017, 172, 173-189. [CrossRef] [PubMed]

35. Escalante, T.; Franceschi, A.; Rucavado, A.; Gutiérrez, J.M. Effectiveness of batimastat, a synthetic inhibitor of matrix metalloproteinases, in neutralizing local tissue damage induced by BaP1, a hemorrhagic metalloproteinase from the venom of the snake Bothrops asper. Biochem. Pharmacol. 2000, 60, 269-274. [CrossRef]

36. Villalta-Romero, F.; Gortat, A.; Herrera, A.E.; Arguedas, R.; Quesada, J.; De Melo, R.L.; Calvete, J.J.; Montero, M.; Murillo, R.; Rucavado, A.; et al. Identification of new snake venom metalloproteinase inhibitors using compound screening and rational peptide design. ACS Med. Chem. Lett. 2012, 3, 540-543. [CrossRef] [PubMed]

37. Arias, A.S.; Rucavado, A.; Gutiérrez, J.M. Peptidomimetic hydroxamate metalloproteinase inhibitors abrogate local and systemic toxicity induced by Echis ocellatus (saw-scaled) snake venom. Toxicon 2017, 132, 40-49. [CrossRef] [PubMed]

38. Flipo, M.; Charton, J.; Hocine, A.; Dassonneville, S.; Deprez, B.; Deprez-Poulain, R. Hydroxamates: Relationships between structure and plasma stability. J. Med. Chem. 2009, 52, 6790-6802. [CrossRef] [PubMed]

39. Beattie, G.J.; Smyth, J.F. Phase I Study of intraperitoneal metalloproteinase inhibitor BB94 in patients with maglinant ascites. Clin. Cancer Res. 1998, 4, 1899-1902. [PubMed]

40. Millar, A.W.; Brown, P.D.; Moore, J.; Galloway, W.A.; Cornish, A.G.; Lenehan, T.J.; Lynch, K.P. Results of single and repeat dose studies of the oral matrix metalloproteinase inhibitor marimastat in healthy male volunteers. Br. J. Clin. Pharmacol. 1998, 45, 21-26. [CrossRef] [PubMed]

41. Ferreira, F.B.; Pereira, T.M.; Souza, D.L.N.; Lopes, D.S.; Freitas, V.; Ávila, V.M.R.; Kümmerle, A.E.; Sant'Anna, C.M.R. Structure-based discovery of thiosemicarbazone metalloproteinase inhibitors for hemorrhage treatment in snakebites. ACS Med. Chem. Lett. 2017, 8, 1136-1141. [CrossRef] [PubMed]

42. Laustsen, A.H. Recombinant Antivenoms. Ph. D. thesis, University of Copenhagen, Copenhagen, Denmark, 2016.

43. Titus, J.K.; Kay, M.K.; Glaser, C.D.R.J.J.; Hwang, Y.Y. Application of phage display for the development of a novel inhibitor of PLA 2 activity in western cottonmouth venom. J. Venom Res. 2017, 8, 19-24. [PubMed]

44. Karain, B.D.; Lee, M.K.H.; Hayes, W.K. C60 Fullerenes as a novel treatment for poisoning and envenomation: A proof-of-concept study for snakebite. J. Nanosci. Nanotechnol. 2016, 16, 7764-7771. [CrossRef]

45. Wikimedia Commons. Buckminsterfullerene. Available online: https://commons.wikimedia.org/wiki/File: Buckminsterfullerene.svg (accessed on 8 April 2018).

46. O'Brien, J.; Lee, S.-H.; Onogi, S.; Shea, K.J. Engineering the protein corona of a synthetic polymer nanoparticle for broad-spectrum sequestration and neutralization of venomous biomacromolecules. J. Am. Chem. Soc. 2016, 138, 16604-16607. [CrossRef] [PubMed]

47. Sharma, T.K.; Bruno, J.G.; Dhiman, A. ABCs of DNA aptamer and related assay development. Biotechnol. Adv. 2017, 35, 275-301. [CrossRef] [PubMed] 
48. El-Aziz, T.M.A.; Ravelet, C.; Molgo, J.; Fiore, E.; Pale, S.; Amar, M.; Al-Khoury, S.; Dejeu, J.; Fadl, M.; Ronjat, M.; et al. Efficient functional neutralization of lethal peptide toxins in vivo by oligonucleotides. Sci. Rep. 2017, 7, 7202. [CrossRef] [PubMed]

49. Muyldermans, S. Nanobodies: Natural single-domain antibodies. Annu. Rev. Biochem. 2013, 82, 775-797. [CrossRef] [PubMed]

50. Cook, D.A.N.; Samarasekara, C.L.; Wagstaff, S.C.; Kinne, J.; Wernery, U.; Harrison, R.A. Analysis of camelid IgG for antivenom development: Immunoreactivity and preclinical neutralisation of venom-induced pathology by IgG subclasses, and the effect of heat treatment. Toxicon 2010, 56, 596-603. [CrossRef] [PubMed]

51. Anderson, G.P.; Liu, J.H.; Zabetakis, D.; Liu, J.L.; Goldman, E.R. Thermal stabilization of anti- $\alpha$-cobratoxin single domain antibodies. Toxicon 2017, 129, 68-73. [CrossRef] [PubMed]

52. Richard, G.; Meyers, A.J.; McLean, M.D.; Arbabi-Ghahroudi, M.; MacKenzie, R.; Hall, J.C. In vivo neutralization of alpha-cobratoxin with high-affinity llama single-domain antibodies (VHHs) and a VHH-Fc antibody. PLoS ONE 2013, 8, e69495. [CrossRef] [PubMed]

53. Julve Parreño, J.M.; Huet, E.; Fernández-del-Carmen, A.; Segura, A.; Venturi, M.; Gandía, A.; Pan, W.S.; Albaladejo, I.; Forment, J.; Pla, D.; et al. A synthetic biology approach for consistent production of plant-made recombinant polyclonal antibodies against snake venom toxins. Plant Biotechnol. J. 2018, 16, 727-736. [CrossRef] [PubMed]

54. Kuczewski, M.; Schirmer, E.; Lain, B.; Zarbis-Papastoitsis, G. A single-use purification process for the production of a monoclonal antibody produced in a PER.C6 human cell line. Biotechnol. J. 2011, 6, 56-65. [CrossRef] [PubMed]

55. Wiberg, F.C.; Rasmussen, S.K.; Frandsen, T.P.; Rasmussen, L.K.; Tengbjerg, K.; Coljee, V.W.; Sharon, J.; Yang, C.-Y.; Bregenholt, S.; Nielsen, L.S.; et al. Production of target-specific recombinant human polyclonal antibodies in mammalian cells. Biotechnol. Bioeng. 2006, 94, 396-405. [CrossRef] [PubMed]

56. Rasmussen, S.K.; Næsted, H.; Müller, C.; Tolstrup, A.B.; Frandsen, T.P. Recombinant antibody mixtures: Production strategies and cost considerations. Arch. Biochem. Biophys. 2012, 526, 139-145. [CrossRef] [PubMed]

57. Thompson, N.J.; Hendriks, L.J.A.; De Kruif, J.; Throsby, M.; Heck, A.J.R. Complex mixtures of antibodies generated from a single production qualitatively and quantitatively evaluated by native Orbitrap mass spectrometry. MAbs 2014, 6, 197-203. [CrossRef] [PubMed]

58. Laustsen, A.H. Costing recombinant antivenoms. Nat. Corresp. 2016, 538, 41.

59. Laustsen, A.H.; Johansen, K.H.; Engmark, M.R. Andersen recombinant snakebite antivenoms: A cost-effective solution to a neglected tropical disease? PLoS Negl. Trop. Dis. 2017, 11, e0005361. [CrossRef] [PubMed]

60. Walsh, G. Biopharmaceutical benchmarks 2014. Nat. Biotechnol. 2014, 32, 992-1000. [CrossRef] [PubMed]

61. Olinger, G.G.; Pettitt, J.; Kim, D.; Working, C.; Bohorov, O.; Bratcher, B.; Hiatt, E.; Hume, S.D.; Johnson, A.K.; Morton, J.; et al. Delayed treatment of Ebola virus infection with plant-derived monoclonal antibodies provides protection in rhesus macaques. Proc. Natl. Acad. Sci. USA 2012, 109, 18030-18035. [CrossRef] [PubMed]

62. Murin, C.D.; Fusco, M.L.; Bornholdt, Z.A.; Qiu, X.; Olinger, G.G.; Zeitlin, L.; Kobinger, G.P.; Ward, A.B.; Saphire, E.O. Structures of protective antibodies reveal sites of vulnerability on Ebola virus. Proc. Natl. Acad. Sci. USA 2014, 111, 17182-17187. [CrossRef] [PubMed]

63. Juárez-González, V.R.; Riaño-Umbarila, L.; Quintero-Hernández, V.; Olamendi-Portugal, T.; Ortiz-León, M.; Ortíz, E.; Possani, L.D.; Becerril, B. Directed evolution, phage display and combination of evolved mutants: A strategy to recover the neutralization properties of the $\mathrm{scFv}$ version of $\mathrm{BCF} 2$ a neutralizing monoclonal antibody specific to scorpion toxin Cn2. J. Mol. Biol. 2005, 346, 1287-1297. [CrossRef] [PubMed]

64. Riaño-Umbarila, L.; Olamendi-Portugal, T.; Morelos-Juárez, C.; Gurrola, G.B.; Possani, L.D.; Becerril, B. A novel human recombinant antibody fragment capable of neutralizing Mexican scorpion toxins. Toxicon 2013, 76, 370-376. [CrossRef] [PubMed]

65. Rodríguez-Rodríguez, E.R.; Olamendi-Portugal, T.; Serrano-Posada, H.; Arredondo-López, J.N.; Gómez-Ramírez, I.; Fernández-Taboada, G.; Possani, L.D.; Anguiano-Vega, G.A.; Riaño-Umbarila, L.; Becerril, B. Broadening the neutralizing capacity of a family of antibody fragments against different toxins from Mexican scorpions. Toxicon 2016, 119, 52-63. [CrossRef] [PubMed] 
66. Espino-Solis, G.P.; Riaño-Umbarila, L.; Becerril, B.; Possani, L.D. Antidotes against venomous animals: State of the art and prospectives. J. Proteom. 2009, 72, 183-199. [CrossRef] [PubMed]

67. Funayama, J.C.; Pucca, M.B.; Roncolato, E.C.; Bertolini, T.B.; Campos, L.B.; Barbosa, J.E. Production of human antibody fragments binding to melittin and phospholipase A2 in Africanised bee venom: Minimising venom toxicity. Basic Clin. Pharmacol. Toxicol. 2012, 110, 290-297. [CrossRef] [PubMed]

68. Pucca, M.B.; Zoccal, K.F.; Roncolato, E.C.; Bertolini, T.B.; Campos, L.B.; Cologna, C.T.; Faccioli, L.H.; Arantes, E.C.; Barbosa, J.E. Serrumab: A human monoclonal antibody that counters the biochemical and immunological effects of tityus serrulatus venom. J. Immunotoxicol. 2012, 9, 173-183. [CrossRef] [PubMed]

69. Pucca, M.B.; Cerni, F.A.; Peigneur, S.; Arantes, E.C.; Tytgat, J.; Barbosa, J.E. Serrumab: A novel human single chain-fragment antibody with multiple scorpion toxin-neutralizing capacities. J. Immunotoxicol. 2014, 11, 133-140. [CrossRef] [PubMed]

70. Tamarozzi, M.B.; Soares, S.G.; Marcussi, S.; Giglio, J.R.; Barbosa, J.E. Expression of recombinant human antibody fragments capable of inhibiting the phospholipase and myotoxic activities of Bothrops jararacussu venom. Biochim. Biophys. Acta Gen. Subj. 2006, 1760, 1450-1457. [CrossRef] [PubMed]

71. Silva, L.C.; Pucca, M.B.; Pessenda, G.; Campos, L.B.; Martinez, E.Z.; Cerni, F.A.; Barbosa, J.E. Discovery of human scFvs that cross-neutralize the toxic effects of B. jararacussu and C. d. terrificus venoms. Acta Trop. 2018, 177, 66-73. [CrossRef] [PubMed]

(C) 2018 by the authors. Licensee MDPI, Basel, Switzerland. This article is an open access article distributed under the terms and conditions of the Creative Commons Attribution (CC BY) license (http://creativecommons.org/licenses/by/4.0/). 